\title{
SLE-like and sicca symptoms in late component (C9) complement deficiency
}

\author{
M SUGIMOTO, ${ }^{1}$ M NISHIKAI, ${ }^{1}$ A SATO,${ }^{1}$ Y SUZUKI, ${ }^{2}$ M NIHEI, ${ }^{2}$ \\ J UCHIDA, ${ }^{2}$ AND N MIMURA ${ }^{2}$
}

From the ${ }^{l}$ Department of Internal Medicine and Clinical Study, Second Tokyo National Hospital, Tokyo; and the ${ }^{2}$ Kidney Center, Toranomon Hospital, Kanagawa, Japan

SUMMARY Hereditary deficiencies in early and late complement components are well known to predispose to SLE-like syndromes or recurrent infection. Hitherto reported C9 deficient cases have usually been healthy subjects, however, and it is not considered that C 9 deficiency is associated with any specific disease. We describe a completely C9 deficient patient with possible Sjögren's syndrome and discuss the relationship.

It has been reported that a deficiency of specific complement (C) components, especially $\mathrm{C} 2$ and $\mathrm{C} 4$, may predispose to systemic lupus erythematosus (SLE), or SLE-like syndromes. ${ }^{1}$ C9 deficiency (C9D) was first described by Inai et al in $1979 .{ }^{2}$ In this paper we describe a case of complete C9 deficiency with possible Sjögren's syndrome.

\section{Case report}

In February 1983 a 48 year old Japanese housewife developed dry eyes, dry mouth, fever, joint pain, and weight loss and two months later was admitted to our hospital. On physical examination she was thin, pale, and febrile $\left(37 \cdot 6^{\circ} \mathrm{C}\right)$. Lymph nodes were swollen in the cervical and inguinal regions bilaterally. The liver was slightly enlarged, but the spleen was not palpable. Neurological examination showed no abnormal findings. Her peripheral joints did not show any objective findings of active synovitis, though she had a past history of arthralgia.

Laboratory tests showed haemoglobin $10.5 \mathrm{~g} / \mathrm{dl}$ $(105 \mathrm{~g} / \mathrm{l})$, white blood cells $2800 / \mathrm{mm}^{3}\left(2 \cdot 8 \times 10^{9} / 1\right)$ platelet count $29 \cdot 1 \times 10^{4} / \mathrm{mm}^{3}\left(291 \times 10^{9} / 1\right)$, normal liver function, normal renal function, normal serum electrolyte values, and normal urine analysis.

Antinuclear antibodies (ANA) by the indirect immunofluorescence method with rat liver cells as a

Accepted for publication 16 June 1986.

Correspondence to $\operatorname{Dr} M$ Nishikai, Second Tokyo National Hospital, 2-5-1 Higashigaoka, Meguro-ku. Tokyo, Japan 152. substrate and the rheumatoid factor were negative. LE cells and antinative deoxyribose nucleic acid (DNA) antibody by passive haemagglutination and the Crithidia method were negative. Precipitating antibodies to $\mathrm{Sm}$, nuclear RNP, Ro/SSA, and $\mathrm{La} / \mathrm{SSB}$ were all absent. $\mathrm{C} 3$ and $\mathrm{C} 4$ values were normal, but despite repeated assays the $\mathrm{CH}_{50}$ value was always low $(5-15 \mathrm{U} / \mathrm{ml}$; normal $30-40 \mathrm{U} / \mathrm{ml})$. A chest radiograph showed no remarkable findings. The electrocardiogram was normal. The gum test (stimulated whole salivary flow rate using chewing gum as stimulant) was $11 \mathrm{ml} / 10 \mathrm{~min}$ (normal $>10$ $\mathrm{ml} / 10 \mathrm{~min}$ ). The sialogram and biopsy of the labial gland were normal. The rose bengal test, fluorescent test, and Schirmer's test (right $1 \mathrm{~mm}$, left $5 \mathrm{~mm}$ ) were all positive, indicating the presence of keratoconjunctivitis sicca. Biopsy of the cervical and inguinal lymph nodes showed non-specific lymphadenitis. On admission she had a recurrent oral ulcer, which was improved by the administration of $20 \mathrm{mg}$ of prednisolone daily. Later she occasionally fainted for a few minutes and had transient global amnesia for several hours, but an electroencephalogram, brain computed tomographic scan, and cerebrospinal fluid study showed no remarkable findings.

Since $\mathrm{CH}_{50}$ levels of her sera always showed less than half of the normal level, her other complement components were studied (Table 1). Values of $\mathrm{C} 1 \mathrm{INH}, \mathrm{C} 1 \mathrm{q}, \mathrm{C} 2$, factor $\mathrm{B}(\mathrm{Bfs})$, and $\mathrm{C} 5$ were all normal, but the $\mathrm{C} 9$ component was undetectable. 
154 Sugimoto, Nishikai, Sato, et al

Table 1 Complement components profile of the patient

\begin{tabular}{|c|c|c|c|c|c|c|c|c|c|c|c|}
\hline & $\mathrm{CH}_{511}$ & $\mathrm{CIINH}$ & $\mathrm{Clq}$ & $C I$ & $C 4$ & $C 2$ & $B$ & C3 & $C 5$ & $C 9$ & $C 3 T$ \\
\hline \multicolumn{12}{|l|}{ Normal pool serum* } \\
\hline Hacmolytic assay $(\mathrm{U} / \mathrm{ml})$ & $40(10)$ & 2253 & & 55000 & 120000 & 630 & & 91000 & 60000 & 68000 & 2400 \\
\hline Protein assay & & & $\begin{array}{l}10 \cdot 0(26) \\
(\%)\end{array}$ & & $\begin{array}{l}22(13) \\
(\mathrm{mg} / \mathrm{dl})\end{array}$ & & $\begin{array}{l}16(8) \\
(\mathrm{mg} / \mathrm{dl})\end{array}$ & $\begin{array}{l}65(16) \\
(\mathrm{mg} / \mathrm{dl})\end{array}$ & $\begin{array}{l}100(30) \\
(\%)\end{array}$ & $\begin{array}{l}100 \\
(\%)\end{array}$ & \\
\hline \multicolumn{12}{|l|}{ Paticnt } \\
\hline Hacmolytic assay $(\mathrm{U} / \mathrm{ml})$ & 15 & 4224 & & 20000 & 77000 & 500 & & 31000 & 35000 & 0 & 0 \\
\hline Protcin assay & & & $\begin{array}{l}102 \\
(\%)\end{array}$ & & $\begin{array}{l}17 \\
(\mathrm{mg} / \mathrm{dl})\end{array}$ & & $\begin{array}{l}11 \cdot 0 \\
(\mathrm{mg} / \mathrm{dl})\end{array}$ & $\begin{array}{l}70 \\
(\mathrm{mg} / \mathrm{dl})\end{array}$ & & ND $\ddagger$ & \\
\hline
\end{tabular}

*Values are mean (2 SD).

$\doteqdot$ Protein assay values are given in $\mathrm{mg} / \mathrm{dl}$ or $\%$ normal human serum. $\ddagger$ ND $=$ not detected.

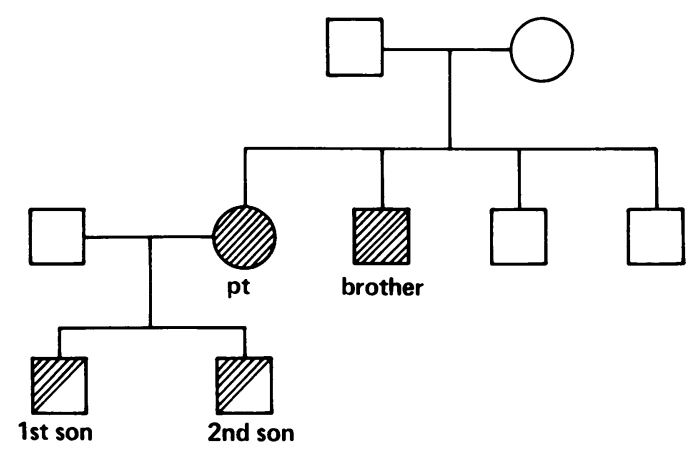

Fig. 1 Pedigree of the C9 deficient family. $\square=$ male; $\mathrm{O}=$ female; $\square, \mathrm{O}=$ not examined; $\square=$ homozygote (completely deficient); $\square, \emptyset=$ heterozygote (partially deficient).

The C9 haemolytic level was fully recovered when purified C 9 was added to her serum. Accordingly, she was diagnosed as having C9D. In addition, study of her family showed that her brother had complete C9D and that both her sons had partial C9D. (Fig. 1).

\section{Discussion}

The significance of complement deficiency (CD) in the pathogenesis of connective tissue diseases is not clearly understood, but the association of CD with connective tissue diseases has been supported by an increased incidence of SLE or related syndromes in patients with $\mathrm{CD}$.

In this patient the clinical features suggest some type of rheumatic disease, but most of the features were not disease specific. The oral ulcer, which responded to prednisolone therapy, and the arthralgia were compatible with SLE, but no serological confirmation was obtained. Dry eyes and ophthalmological examinations indicated the presence of keratoconjunctivitis sicca. Therefore, a diagnosis of Sjögren's syndrome with complete C9D appeared most likely. Family studies indicated that the de- $\vec{\omega}$ ficiency was inherited as an autosomal dominanto trait (Fig. 1).

Previously reported Japanese cases of $\mathrm{C} \mathrm{D}_{\bar{T}}$ showed it to occur in usually healthy subjects and among them recurrent infections were seen onlye very rarely. ${ }^{2}{ }^{3}$ The studies on C9D sera haemolytic and bactericidal activity showed that the rates of cytolysis of erythrocytes and bacteria were slowerginno the C9 deficient sera, but reached completing eventually. ${ }^{45}$ Furthermore, no increased susce bility to viral disease has been observed in patients with C9D. For these reasons it appears unlikely thato such deficiency would, through persistence of ano infectious agent, result in a connective tissuea disease.

Early component deficiency may impair comple- 3 ment function in solubilisation of immune com-? plexes and decrease their clearance. But it has been? reported that late components $(\mathrm{C} 5, \mathrm{C} 6, \mathrm{C} 7, \mathrm{C} 8$, andw C9) are not involved in this phenomenon. ${ }^{6}$ Accor? dingly, in a late component deficient state such as? C9D, abnormal immune clearance cannot be incriminated in the development of the associated? connective tissue disease.

On the other hand, it has been shown that botho connective tissue diseases and $C D$ are linked with HLA. For example, the loci which are associatedE. with SLE are DR3 in Caucasians ${ }^{7}$ and DR4 inf Japanese. ${ }^{8}$ In addition, it is clear that there is a close linkage between the genetic loci for $\mathrm{Bfs}, \mathrm{C} 2$, and $\mathrm{C} 4 \mathrm{P}$ and those for HLA, ${ }^{9}$ and close positive linkage isw well established between the C2D gene and HLA genes A10, ${ }^{10} \mathrm{~B} 18,{ }^{1} \mathrm{Dw} 2,{ }^{11} \mathrm{DR} 2,{ }^{12}$ and between the C4D gene and HLA genes A2, Bw40, Cw3. 总 Therefore, it is conceivable that $\mathrm{CD}$ is in linkage disequilibrium with a defective immune response gene, leading to connective tissue disease.

These linkages may determine the susceptibility 
to connective tissue diseases in complement deficient patients. Although there have been no reports yet suggesting a linkage between C9D and HLA, in deficiency of $\mathrm{C} 8$, which has similar functions to $\mathrm{C}$, two cases with SLE have been reported. ${ }^{14} 15$

Although the relation between $C D$ and connective tissue diseases is not understood, it is supported by the many cases of SLE or SLE-like syndrome that have been reported in patients with $C D$, some of them in late component deficiency. ${ }^{14-18}$ In the lupus syndrome seen in complement deficient patients the less positive serology, including ANA and antinative DNA antibodies, is one of the characteristics. ${ }^{1}$ So we must follow up this patient carefully to see whether she develops definite SLE or Sjögren's syndrome, or both in the future. Until now it has been believed that nothing connects C9D with any connective tissue disease and that its clinical significance is extremely limited. The existence of this case of a systemic rheumatic syndrome with C9D, however, suggests a relation with connective tissue disease similar to that of other CD.

\section{References}

1 Agnello V. Complement deficiency states. Medicine (Baltimore) 1978; 57: 1-23.

2 Inai S, Kitamura H, Hiramatsu S, Nagaki K. Deficiency of the ninth component of complement in man. J Clin Lab Immunol 1979; 2: 85-7.

3 Kitamura H, Nagaki K, Inai S. Further studies on C9 deficiency. J Clin Lab Immunol 1981; 6: 7-11.

4 Lint T F, Zeite H J, Gewurz H. Inherited deficiency of the ninth component of complement in man. J Immunol 1980; 125: 2252-7.

5 Harriman G R, Esser A F, Podack E R, et al. The role of C9 in complement-mediated killing of Neisseria. J Immunol 1981; 127: 2386-90.

6 Takahashi M, Czop C, Ferreira A. Nussenzweig V. Mechanism of solubilization of immune aggregates by complement. Implications for immunopathology. Transplant Rev 1976; 32: 121-39.

7 Black C M, Welsh K I, Fielder A. Hughes G R V, Batchelor J R. HLA antigens and Bf allotypes in SLE. Tissue Antigens 1982; 19: 115-20.

8 Kamada S, Naito S. Tanaka K, et al. HLA antigens of patients with systemic lupus erythematosus in Japan. Tissue Antigens 1982: 20: 221-2.

9 Alper C A. Complement and the MHC. In: Dorf M E, ed. The role of the major histocompatibility complex in immunology. New York and London: Garl and STPM Press, 1981: 173-220.

10 Fu S M. Kunkel H G. Brusman H P. Allen F H Jr, Fotion M. Evidence for linkage between HL-A histocompatibility genes and those involved in the synthesis of the second component of complement. J Exp Med 1974; 140: 1108-11.

11 Schur P H. Genetics of complement deficiencies associated with lupus-like syndrome. Arthritis Rheum 1978; 21 (suppl): 153-60.

12 McCarty D J. Tan E M. Zvaifler N J, Kocthe S, Duguesnoy R $\mathrm{J}$. Serologic studies in a family with heterozygous $\mathrm{C} 2$ deficiency. Am J Med 1981; 71: 945-8.

13 Richter C H, Hauptmann G. Grosse-Wilde H. Tongio M M, Mayr S. Linkage between HL-A (major histocompatibility complex) and genes controlling the synthesis of the fourth component of complement. In: Kissmeyer-Nielsen F, ed. Histocompatibility testing. Copenhagen: Villadsen and Christensen, 1975: 945-53.

14 Jasin H E. Absence of the eighth component of complement in association with systemic lupus erythematosus-like disease. $J$ Clin Invest 1977; 60: 709-15.

15 Pickering R J. Rynes R I. Locascio N. Monahan J B. Sodetz J $M$. Identification of the alpha-gamma subunit of the eighth component of complement (C8) in a patient with systemic lupus erythematosus and absent C8 activity: patients and family studies. Clin Immunol Immunopathol 1982; 23: 323-34.

16 Rosenfeld S I. Kelly M E. Lebby J P. Hereditary deficiency of the fifth component in man. J Clin Invest 1976; 57: 1626-43.

17 Trapp R G, Mooney E, Hussain I, Coleman T H, Forrestal J, Herman J H. Hereditary complement (C6) deficiency with discoid lupus/Sjögren's syndrome. Proceedings of the Annual Meeting of the Heberden Society, London 1980.

18 Zeitz H J, Miller G W, Lint T F. Ali M A. Gewurz H. Deficiency of $\mathrm{C7}$ with systemic lupus erythematosus. Solubilization of immune complexes in complement deficient sera. Arthritis Rheum 1981; 24: 87-93. 